\title{
Impact of the Sanitation Regime on Production Safety of Paff Pastry in the Food Processing Plant
}

\author{
Katarína Veszelits Lakticova ${ }^{1}$, Mária Vargova ${ }^{2}$, František Zigo ${ }^{3 *}$ \\ ${ }^{1}$ Department of the Environment, Veterinary Legislation and Economy, University of Veteriny Medicine and Pharmacy \\ Košice, Slovakia \\ Email: katarina.veszelitslakticova [AT] uvlf.sk
}

${ }^{2}$ Department of the Environment, Veterinary Legislation and Economy, University of Veteriny Medicine and Pharmacy Košice, Slovakia

Email: maria.vargova [AT] uvlf.sk

\author{
${ }^{3}$ Department of Nutrition and Animal Husbandry, University of Veterinary Medicine and Pharmacy \\ Košice, Slovakia \\ *Corresponding author's email: frantisek.zigo [AT] uvlf.sk
}

\begin{abstract}
Food is essential for a person's life, it is a source of energy and substances that enable the activity of all his organs. However, food is also a biological substance, which itself is subject to certain changes, sometimes targeted in their production or cooking, sometimes undesirable changes due to the activity of certain food components or the action of microorganisms. The primary role of each food processing plant should be to ensure daily proper cleaning and sanitation, thus ensuring perfect hygiene of the premises in operation due to the prevention of foodborne diseases. Based on the results obtained in our study, we can concluce that the sanitation regime in the evaluated premises of paff pastry production is at a good level and the disinfection in the production of puff pastry is effective. Aspiral Persteril 15 disinfectant at $0.4 \%$ concentration and time exposure of 30 minutes was effective on all evaluated surfaces in individual monitored parts of production with the exception of puff pastry production part, where we recorded on technology, specifically on slicing knife 35 CFU (colony forming units) of total count of bacteria and 3 CFU of coliform bacteria after disinfection. The situation did not improve even until the begining of production, the total count of bacteria increase to 45 CFU and coliform bacteria to 4 CFU.
\end{abstract}

Keywords-Sanitation Regime, Disnfection, Aspiral Persteril 15, Paff Pastry, Microbiological Swabs

\section{INTRODUCTION}

Food production as well as food itself can be contaminated by microorganisms that enter the environment. The occurrence of microorganisms in the environment increases with insufficient cleaning and incorrect disinfection of surfaces. Biofilms are formed and microorganisms survive in hard-to-reach places [1].

Alimentary diseases are diseases that arise after the consumption of contaminated food, we divide them into diseases of non-microbial and microbial origin. Alimentary diseases include enterotoxicosis and toxoinfections. The disease manifests itself as having an acute course and is caused by the ingestion of contaminated food containing conditionally pathogenic or pathogenic bacteria. They are characterized by diarrhea, vomiting, and nervous symptoms are possible [2].

Cleaning of premises and technological equipment in food production is a crucial part of hygiene and has an immediate impact on the result of disinfection. In this form, it becomes a waste that complicates the operation (eg slippery floor), or creates a breeding ground for the growth of undesirable microflora in the environment, which can negatively affect the quality of manufactured products. This layer formed in food operations is reffered biofilm and is composed of proteins, fats and other ingredients used in production [3].

Biofilm formation is generally characterized by the capture, colonization, and growth of microorganisms [4]. The responsibility of how the bacterium adheres to surfaces is based on physicochemical properties [5]. It manifests itself in the food industry as a health risk. It causes secondary contamination in direct contact with food and subsequent contamination, quality reduction and decomposition [6].

Biofilm is formed by bacteria of all types of more resistant microorganisms. The most common are Pseudomonas, Bacillus, Flavobacterium and Enterobacter. They adapt better to the environment and use food efficiently. The biofilm for microorganisms in a given environment creates both a nutritional layer that allows their reproduction, but also a protective layer that limits the devitalizing effects of the disinfectants used [7]. 
An important part of food safety is the effective management of hygiene staff. These are the most critical points of hygienic intervention in the production process. The transmission of pathogens from staff is more likely than any other possibility of contamination [8].

The role of disinfection consists in reducing pathogenic microorganisms to such an extent that it is not able to cause dangerous diseases in consumers. A large number of factors affect the effect of disinfection. The effect of the environment is influenced not only by its composition and structure of production surfaces, but also by the degree of organic load, type and amount of microorganism occurring, ambient temperature and materials, as well as hardness and quality of water used to prepare disinfectant solution [9].

In the food industry, disinfectants and cleaning agents should be characterized by a high ability to devitalize microorganisms in very low concentrations as well as not to leave residues and load the environment [10].

The work is focused on the evaluation of the sanitation regime in the premises of the puff pastry production plant.

\section{MATERIAL AND METHOD}

The evaluated food production is located in central Slovakia, it is one of the large plants, the resulting product of which is frozen puff pastry and cakes. The sanitation plan in operation must be carefully observed and effective. The production of deep-frozen puff pastry is separated from the cakes per week. Continuous cleaning is carried out after the end of the puff pastry production to such an extent that operational cleanliness is ensured in the production, auxiliary and storage areas. Large disinfection of the entire plant is performed once a week.

We evaluated hygiene of the different surfaces in puff pastry production plant (Figure 1,2). The evaluated parts of the operation were part of the production and packing of puff pastry. The quality of the surfaces were evaluated by microbiological swabs during work, after disinfection and before starting work. Individual swabs were taken from various surfaces of the production line, floors and walls. The evaluated area $\left(10 \mathrm{~cm}^{2}\right)$ was wiped with a wetted cotton swab. The microbiological swabs were put in $10 \mathrm{ml}$ of a saline solution. From the mixture obtained $0.1 \mathrm{ml}$ was applied to Meat peptone agar and Endo agar [11]. Agars were evaluated after 24 hours cultivation at $37^{\circ} \mathrm{C}$. The results of the total count of bacteria (TCB) and coliform bacteria (CB) were evaluated in CFU (colony forming units) units.

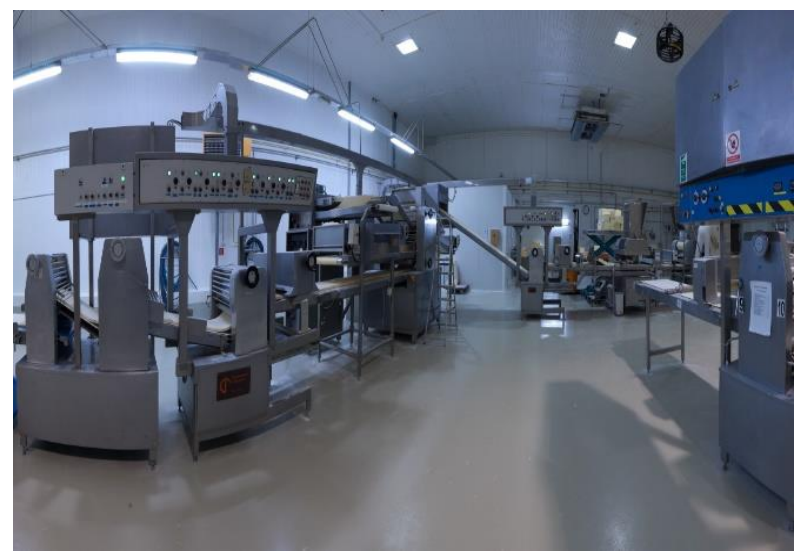

Figure 1 : Operation with puff pastry production

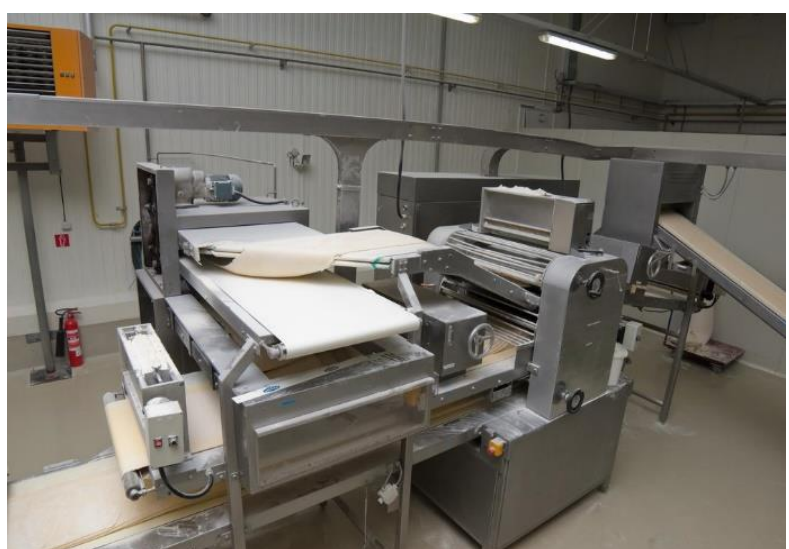

Figure 2: Part of puff pastry technology

In this work, we focused on the evaluation of the disinfection efficiency of the commercially produced disinfectant Aspiral Persteril 15 (Figure 3), which was used to disinfect the premises in the evaluated operation. 


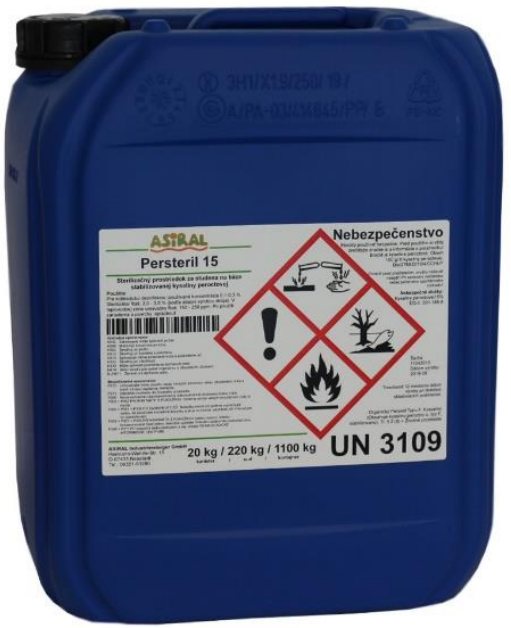

Figure 3: Disinfectant Aspiral Persteril 15 used in evaluated plant

Asiral PL 15 is a Persteril liquid, acidic, disinfectant, non-foaming (without defoamer) based on peracetic acid, for cold use, for disinfection of floors, walls, tanks, pipes, machines, CIP equipment. Effectively eliminates bacteria, yeasts, fungi, viruses and spores. It is effective against listeria. Aspiral Persteril 15 disinfectant is used in the meat industry, in the dairy industry, in the beverage industry, in the food industry, in agriculture. Disinfectant is used for surface disinfection in a working concentration of $0.1-0.5 \%$. The maximum water temperature must be $40-45^{\circ} \mathrm{C}$. Dosage of the product is low, 0.5 $\%$ solution is enough to prevent it, manually, with a sprayer, dosing device.The manufacturer of Aspiral Persteril 15 is Ronchem CZ, s.r.o.

\section{RESULTS AND DISCUSSION}

Table 1 evaluates the hygiene of individual monitored surfaces of the plant. The obtained results of the evaluated microorganisms indicate the microbial purity of the evaluated surfaces. During production, we recorded a higher total count of bacteria on the wall and floor and the handling table. After disinfection, the presence of microorganisms, coliform bacteria decrease to zero. Before starting work, we recorded the same number of evaluated microorganisms as were recorded after disinfection.

Table 1: Average values of microorganisms on individual tested surfaces in the part of puff pastry production

\begin{tabular}{|c|c|c|c|c|c|c|}
\hline \multirow[t]{4}{*}{$\begin{array}{l}\text { Place of } \\
\text { sampling }\end{array}$} & \multicolumn{2}{|c|}{$\begin{array}{l}\text { Before starting } \\
\text { work }\end{array}$} & \multicolumn{2}{|c|}{ During work } & \multicolumn{2}{|c|}{ After disinfection } \\
\hline & $\mathrm{TCB}$ & $\mathrm{CB}$ & TCB & $\mathrm{CB}$ & $\mathrm{TCB}$ & $\mathrm{CB}$ \\
\hline & $\varnothing$ & $\varnothing$ & $\varnothing$ & $\varnothing$ & $\varnothing$ & $\varnothing$ \\
\hline & $(\mathbf{C F U})$ & $(\mathbf{C F U})$ & (CFU) & (CFU) & (CFU) & (CFU) \\
\hline Working table & 0 & 0 & 25 & 0 & 0 & 0 \\
\hline Floor & 0 & 0 & 65 & 1 & 0 & 0 \\
\hline Wall & 0 & 0 & 24 & 0 & 0 & 0 \\
\hline Manipulation table & 0 & 0 & 15 & 0 & 0 & 0 \\
\hline
\end{tabular}


At present, consumers and producers are much more interested in safe food, which is related to the microbiological purity of food raw materials, technological equipment, production facilities and final products. Therefore, great emphasis is placed on the whole complex of quality assurance, including production hygiene [12].

Table 2 shows the average values of microorganisms on the tested surfaces in the production technologies of the puff pastry production part. Within the technological equipment of puff pastry production, the values of the monitored microorganisms were in the norm. After disinfection, we recorded zero numbers of coliform bacteria and total count of bacteria on all monitored surfaces of the evaluated technologies, with the exception of a slicing knife, where we recorded 35 CFU of total count of bacteria on the surface and until the start of production this number of microorganisms increased to $45 \mathrm{CFU}$. The number of coliform bacteria on the surface of the slicing knife after disinfection was 3 CFU and increased to $4 \mathrm{CFU}$ by the start of production.

Table 2: Average values of microorganisms on the tested surfaces of production technologies in the part of puff pastry production

\begin{tabular}{|c|c|c|c|c|c|c|}
\hline \multirow[t]{4}{*}{ Place of sampling } & \multicolumn{2}{|c|}{$\begin{array}{l}\text { Before starting } \\
\text { work }\end{array}$} & \multicolumn{2}{|c|}{ During work } & \multicolumn{2}{|c|}{ After disinfection } \\
\hline & TCB & $\mathrm{CB}$ & TCB & $\mathrm{CB}$ & TCB & $\mathrm{CB}$ \\
\hline & $\varnothing$ & $\varnothing$ & $\varnothing$ & $\emptyset$ & $\emptyset$ & $\emptyset$ \\
\hline & (CFU) & (CFU) & (CFU) & (CFU) & (CFU) & (CFU) \\
\hline Slicer & 0 & 0 & 12 & 0 & 0 & 0 \\
\hline Margarine cabinet & 0 & 0 & 19 & 1 & 0 & 0 \\
\hline Mixer & 1 & 0 & 15 & 0 & 1 & 0 \\
\hline Pressure roller & 0 & 0 & 6 & 0 & 0 & 0 \\
\hline Slicing knives & 45 & 4 & 25 & 2 & 35 & 3 \\
\hline Sliding belt & 0 & 0 & 5 & 3 & 0 & 0 \\
\hline Guillotine & 0 & 0 & 1 & 1 & 0 & 0 \\
\hline Output conveyor & 0 & 0 & 10 & 1 & 0 & 0 \\
\hline Filler mixer & 0 & 0 & 5 & 0 & 0 & 0 \\
\hline Ladle & 0 & 0 & 10 & 0 & 0 & 0 \\
\hline
\end{tabular}

Sanitation is part of the production processes in the food industry. In case of insufficient surface sanitation, resp. technological equipment may contaminate the processed material, also referred to as "cross-contamination"[13].

If the disinfection program is not effective and pathogens remain in operation in high concentrations, errors will occur that affect food quality and safety [14].

The cause of foodborne diseases does not have to be related only to product contamination, but the focus must be on personal hygiene and the HACCP system [8]. Hand washing and personal hygiene reduce contamination by pathogenic microorganisms. The principle is that what comes into conflict with the product can cause its contamination [15]. 
The manufacturer should ensure that the production process is carried out by a sufficient sanitation process, which should be based on the HACCP system, as it is able to identify the part of production that could adversely affect food and cause foodborne diseases [16].

Table 3 shows the values of the monitored microorganisms collected on individual surfaces in the paff pastry packaging section. During production, we recorded an increased level of pollution. The contamination of the individual monitored surfaces increases in direct proportion to the production process. After disinfection, the values of the total count of bacteria decreased by an order of magnitude and the numbers of coliform bacteria decrease to zero.

Table 3: Average values of microorganisms on individual tested surfaces in the part of the puff pastry packaging section

\begin{tabular}{|c|c|c|c|c|c|c|}
\hline \multirow[t]{4}{*}{ Place of sampling } & \multicolumn{2}{|c|}{$\begin{array}{c}\text { Before starting } \\
\text { work }\end{array}$} & \multicolumn{2}{|c|}{ During work } & \multicolumn{2}{|c|}{ After disinfection } \\
\hline & $\mathrm{TCB}$ & $\mathrm{CB}$ & $\mathrm{TCB}$ & $\mathrm{CB}$ & $\mathrm{TCB}$ & $\mathrm{CB}$ \\
\hline & $\varnothing$ & $\varnothing$ & $\varnothing$ & $\emptyset$ & $\varnothing$ & $\emptyset$ \\
\hline & (CFU) & (CFU) & (CFU) & $(\mathbf{C F U})$ & (CFU) & (CFU) \\
\hline Wall & 0 & 0 & 42 & 0 & 0 & 0 \\
\hline Floor & 10 & 1 & 150 & 2 & 10 & 0 \\
\hline Package & 1 & 0 & 33 & 0 & 1 & 0 \\
\hline Working table & 0 & 0 & 15 & 1 & 0 & 0 \\
\hline Handling trolley & 0 & 0 & 25 & 2 & 0 & 0 \\
\hline
\end{tabular}

Sanitation is a cleaning and disinfection process which, in microbiological terms, leads to a reduction in the number of vegetative bacteria to the limit of up to 99.0 to $99.9 \%$ [17].

Hygiene and quality control of cleaning and disinfection is a decisive factor for fulfillment the basic requirements of the HACCP system in food operations [18].

\section{CONCLUSION}

In our study, we focused on the evaluation of the sanitation regime and its impact on the safe paff pastry production in food processing plant. We evaluated the disinfection efficiency of the disinfectant Aspiral Persteril 15, which is used for sanitizing surfaces in premises of the paff pastry production. Disinfectant was effective on all evaluated surfaces with exception slicing knife, where we detected 35 CFU of total count of bacteria and 3 CFU coliform bacteria after disinfection. The situation did not improve until the begining of production, the total count of bacteria increased to $45 \mathrm{CFU}$ and coliform bacteria to $4 \mathrm{CFU}$. From the obtained results we can conclude that no part of the production process is more important than the cleaning and disinfection of the production equipment itself. The main role of food processing plant is to provide healthy and hygienic food for this reason the suitable choice of disinfectant with correct concentration and exposure time as well as properly performed disinfection is of great importance in terms of food safety.

\section{CONFLICTS OF INTERESTS}

Authors declare that there are no conflicts of interest.

\section{ACKNOWLEDGEMENT}

This work was supported by the Slovak project KEGA NO. 004UVLF-4/2020 'Practical education for pharmacists as a tool for improving the quality of university education from the subject "Health and Pharmaceutical Hygiene'.

\section{REFERENCES}

[1] Podstatová H., Mikrobiologie epidemiologie- hygiena, Vyd. 1. Olomouc, 2006.

[2] Burdová O., Hygiena a technológia mlieka a mliečnych výrobkov, (Vienala), Košice, 2001. 
[3] Hoffman P., Bradley T., Ayliffe, G., Disinfection in healthcare, (Published by Wiley \& Sons), UK, 2004.

[4] Kumar C. G., Anand, S. K., "Significance micorbial biofilms in food industry“, Int. J. Food. Microbiol., vol. 42, pp. 9-27, 1998.

[5] Frank J. F., "Microbial attachment to food and food contact surfaces“, Adv. Food. Nutr. Res., vol. 43, pp. 319-369, 2001.

[6] Vlková H. a kol., "Biofilms and Hygiene on Dairy Farms and in the Dairy“, Czech J. Food Sci., vol. 26, pp. 309- 323, 2008.

[7] Gracey J. F., Collins, D. S. 1992. "Meat hygiene“, 9th edition. Bailliere Tindal: London, pp. 129-130, ISBN: 978-1118-65002-8.

[8] Huerkamp M. J., Michaels J.,"Alcohol as a Disinfectant for Aseptic Surgery of Rodents: Crossing the Thin Blue Line?", Journal of the American Association for Laboratory Animal Science, vol. 41, no.1, pp. 10-12, 2002.

[9] Tittl K., Novák P., "Disinfection, an Integral part of Animal Biosecurity on Farm. In: Proceeding of the XIV“, Congres ISAH, (Germany), 2000.

[10] Drdák M., Studnický J., Mórová E., Karovičová J., Základy potravinárskych technológií, (Malé centrum), Bratislava, 1996.

[11] Davidson C. A., Griffith C. J., Peters C. A., Fielding L. M., "Evaluation of two methods for monitoring surface cleanliness-ATP bioluminescence and traditional hygiene swabbing“, Luninescence, vol. 14, pp. 33-38, 1999.

[12] Lapašovský L'. Popelka P., "Využitie moderných metód pri monitorovaní hygieny prostredia bitúnku“. In: Bezpečnost' a kontrola potravín“, Zborník prác z medzinárodnej vedeckej konferencie (Nitra), 2006.

[13] Šiška B., Golian J., Popelka P., “Využitie metódy 3M Petrifilm pri monitorovaní úrovne hygieny v zariadeniach spoločného stravovania. In: Bezpečnost’ a kontrola potravín“, Zborník prác z medzinárodnej vedeckej konferencie (Nitra), 2006.

[14] Gibson L. L., Rose J. B., Haas C. N., Gerba C. P., Rusin P. A., "Quantitative assessment of risk reduction from hand washing with antibacterial soaps“, J. Appl. Microbiol., vol. 92, Suppl. S1, pp. 136-143, 2002.

[15] Lehto, M., Kuisma, R., Määttä, J., Kymäläinen H. R., "Hygienic level and surface contamination in fresh-cut vegetable production plants“, Food Control, vol. 22, no. 3-4, pp. 469-475, 2011.

[16] Lapašovská J., Petríková J., Koreňová J., Stoleřová K., "Monitoring úrovne hygieny a sanitácie v malých potravinárskych prevádzkach In: Bezpečnost' a kontrola potravín“, Zborník prác z medzinárodnej vedeckej konferencie (Nitra), 2006.

[17] Grušpier, L., Hygiena výrobného prostredia, (Slovenská pol’nohospodárska univerzita), Nitra, 2011.

[18] Vojtaššák J., "Kontrola hygieny pomocou detektoru Lightning MVP“, Mäso, vol. 14, pp. 33 - 35, 2003. 